\begin{tabular}{l|c|c|}
\hline & International Journal of Current Research in \\
Biosciences and Plant Biology \\
EXCELLENT \\
PUBLISHERS
\end{tabular}

\title{
Endophytic Fungi with Potential as Biological Control Agents for Black Pod Rot Disease [Phytophthora palmivora (Butler) Butler]
}

\author{
I. Made Sudarma*, Ni Wayan Suniti² and Ni Nengah Darmiati² \\ *1Staff lecturer of Program Study of Agroecotechnology, 2Faculty of Agriculture, Udayana University, \\ Jl. PB. Sudirman Denpasar-Bali, Indonesia
}

*Corresponding author.

\begin{tabular}{|c|c|}
\hline Article Info & ABSTRACT \\
\hline $\begin{array}{l}\text { Date of Acceptance: } \\
02 \text { April } 2018\end{array}$ & \multirow{4}{*}{$\begin{array}{l}\text { Production and cocoa plantation area in Indonesia decline every year, major causes is } \\
\text { the outbreak of the cocoa black pod disease. Results showed that the antagonistic fungi } \\
\text { found based on the DNA sequences are Lasiodiplodia euphorbicola, Diaporthe tectonae, } \\
\text { Colletotrichum siamense, Aspergillus flavus, Candida parapsilogis, and Aspergillus sydowii. } \\
\text { The results of the best inhibition shown by the endophytic fungus L. euphorbicola, thus } \\
\text { passed field trials which showed that the higher the concentration of spore suspension } \\
\text { the better the power suppress fungal antagonists against P. palmivora. The best } \\
\text { concentration that colonies of the Petri dish was dissolved in } 150 \mathrm{ml} \text { of sugar solution } \\
(10 \%) \text {. }\end{array}$} \\
\hline $\begin{array}{l}\text { Date of Publication: } \\
\text { 06 May } 2018\end{array}$ & \\
\hline Keywords & \\
\hline $\begin{array}{l}\text { Cocoa } \\
\text { DNA sequences } \\
\text { Endophytic fungus } \\
\text { Inhibition ability } \\
\text { Phytophthora palmivora }\end{array}$ & \\
\hline
\end{tabular}

\section{Introduction}

Cocoa plantation area in Indonesia in 2012 - 2015, continue to decline from $1,774,46$ in 2012 to $1,704,982$ ha in 2015. Declining in area coverage resulted in decreasing number of producing per year, from 740,513 to 701,229 tones (Directorate General of Plantation, 2014). The decline was caused by the addition of land conversion is also one of the reasons is due to interference cocoa pod disease caused by $P$. palmivora.
Endophytic fungi isolated from healthy cocoa plant tissue provides new hope in biological control of cacao pod disease. The research by Mejia et al. (2008) $40 \%$ (21/52) of isolated endophytic fungi capable of controlling $P$. palmivora. One fungus findings antagonistic with simple competition mechanism was Trichoderma sp. This fungus can competitively inhibit pathogens and antibiosis.

Fungi are known to colonize certain plants with 
varying degrees and in varying patterns. While some endophytic fungi in part of this material (Amadi, 2005).

Endophytic fungi especially asexual, endophytic grasses generally seen systemic in collaboration with the plant, mainly through the work of mycotoxins such as alkaloids in the infected grass, which protect host plants from herbivores. Very much evidence for defensive mutualism concept originated from cultivars of grass agronomic studies, which may form endophytic-host interaction (Faeth, 2002).

Endophytic fungus to grow which indicates that the endophyte was found in all plants, in extreme plentiful and often very diverse (Arnold et al., 2002). Very much endophyte derived from internal local infections on leaves, roots, stems and bark, as well as horizontally transferred through spores (Faeth, 2002).

Endophytic fungi can secrete mycotoxins or modify the host's physiology and morphology. Endophytic mycotoxins beneficial for host plant timber as a "defense that is able to trigger" face a host insect herbivores and grass as a "desired plant defense" facing both vertebrate and invertebrate herbivores. Endophyte can also change the other physiology, developmental or morphological characteristics of host plants such as changes in the ability of competition, especially in encountering stress on the environment (Malinowski et al., 1999).

\section{Materials and methods}

\section{Place and time of research}

The research was conducted in two places, namely 1) on the ground in the form of looking for healthy plant specimens in the form of leaves, stems and fruit, which is located in Perean village, Tabanan, and 2) Laboratory of Biotechnology, Faculty of Agriculture, University of Udayana, from March to August 2017.

\section{Test of inhibition ability of endophytic fungus in vitro}

Endophytic fungi are found each tested for inhibitory to the growth of pathogenic fungi $(P$. palmivora) with a dual culture technique (in a Petri dish grown each one fungal pathogen flanked by two endophytic fungi). Inhibition ability can be calculated as fellows (Dollar, 2001; Mojica-Marin et al., 2008):

$$
\text { Inhibition ability }(\%)=\frac{\mathrm{A}-\mathrm{B}}{\mathrm{A}} \times 100
$$

Where: $\mathrm{A}=P$. palmivora colony diameter in a single culture $(\mathrm{mm})$;

$\mathrm{B}=P$. palmivora colony diameter in a dual culture $(\mathrm{mm})$.

\section{Antagonistic test in vivo}

In vivo test of antagonistic endophytic fungi were found by pricking with a needle spelden fresh fruit as much as 20 times, then smeared with antagonistic fungus spores (one Petri dish in $250 \mathrm{ml}$ of sterile distilled water). Finally fruits were dipped in a spore suspension of pathogenic fungi ( $P$. palmivora). The treatment of fungal antagonists, include:

$\mathrm{A}=$ control (without smeared with antagonists without pathogens)

$\mathrm{B}=1$ antagonist treatment $\left(5 \times 10^{7}\right.$ spore suspension $)$

$\mathrm{C}=2$ antagonist treatment $\left(5 \times 10^{7}\right.$ spore suspension)

$\mathrm{D}=3$ antagonist treatment $\left(5 \times 10^{7}\right.$ spore suspension)

$\mathrm{E}=4$ antagonist treatment $\left(5 \times 10^{7}\right.$ spore suspension $)$

$\mathrm{F}=5$ antagonist treatment $\left(5 \times 10^{7}\right.$ spore suspension $)$

$\mathrm{G}=6$ antagonist treatment $\left(5 \times 10^{7}\right.$ spore suspension)

$\mathrm{H}=\mathrm{Control}$ (without smeared antagonist with pathogens)

All treatments were repeated for 5 times. The experiment was designed with a randomized block design (RBD), and after analysis of variance (ANOVA) followed by the least significant difference test (LSD) at 5\% level. Attack parameters measured by the formulation: how punctures are attacked by fungi shared with the entire puncture $(20 \times)$ times $100 \%$. 


\section{Antagonistic test in field}

Best antagonist been tested in field by spraying into fruit still attached to the tree. The suspension was made by mixing the best of endophytic fungal colonies into a $10 \%$ sugar solution. The treatments were to plot (cacao tree) is as follows:

$A=$ Control (without treatment).

$\mathrm{B}=$ Treatment with a suspension of spores of the Petri $\mathrm{dish} / 150 \mathrm{ml}$ of sugar solution (10\%).

$\mathrm{C}=$ Treatment with a spore suspension of a Petri $\mathrm{dish} / 200 \mathrm{ml}$ of sugar solution (10\%).

$\mathrm{D}=$ Treatment with a spore suspension of a Petri $\mathrm{dish} / 250 \mathrm{ml}$ of sugar solution (10\%).

$\mathrm{E}=$ Treatment with a spore suspension of a Petri $\mathrm{dish} / 500 \mathrm{ml}$ of sugar solution (10\%).

$\mathrm{F}=$ Treatment premises spore suspension of the Petri dishes/1000 $\mathrm{ml}$ of sugar solution (10\%).
All treatments were repeated for 6 times. The experiment was designed with a randomized block design (RBD), and after analysis of variance (ANOVA) followed by the least significant difference test (LSD) at $5 \%$ level.

\section{Results}

\section{Best endophytic fungi identification by PCR and sequencing}

Results amplification $1.2 \%$ agarose gel electrophoresis in 1x TAE buffer at a voltage of 50 volts for 30 minutes. DNA bands seen above UV Transilluminator. That generate a DNA fragment size of \pm 600 bp (Fig. 1). Furthermore, the DNA fragment was sent to PT Macrogen Inc. Korea to do the nucleotide bases tracing the identity of the fungus.

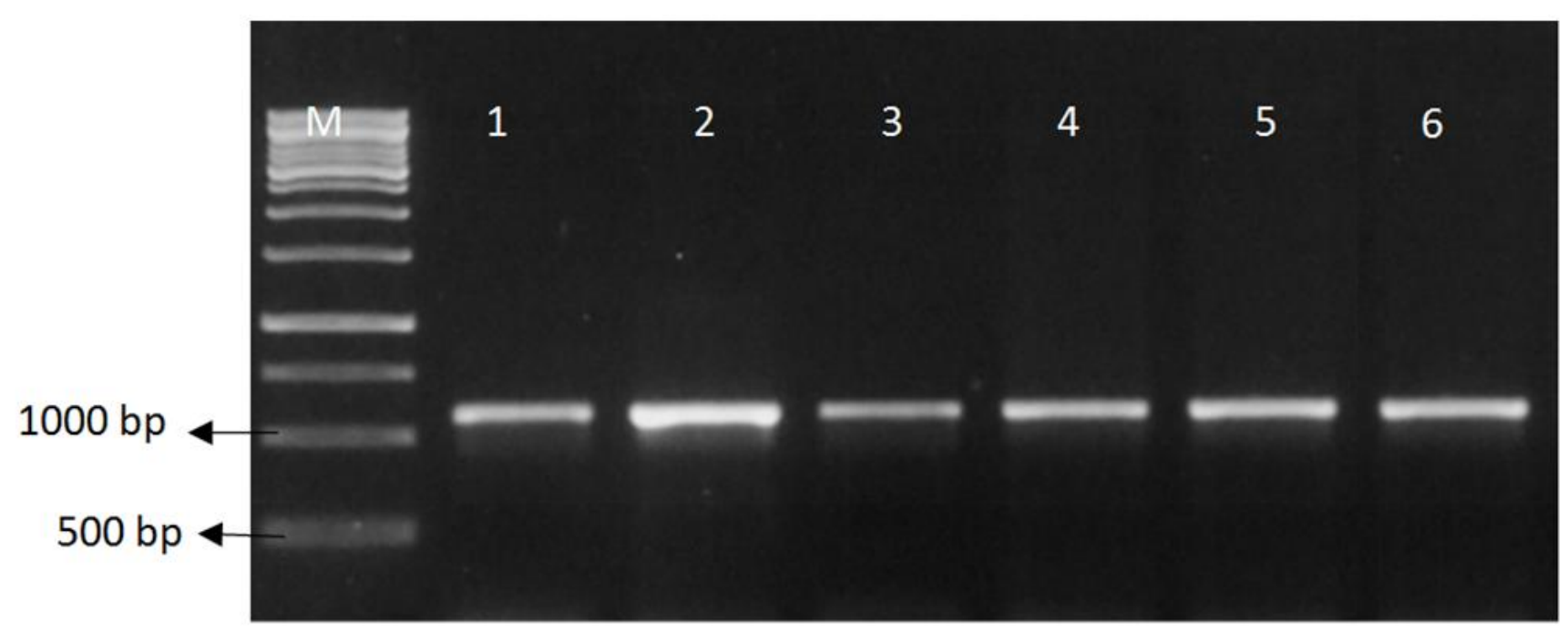

Fig. 1: The DNA fragment of each isolate ( $M=1 \mathrm{~kb}$ DNA leader, 1, 2, 3, 4, 5 and 6 isolates respectively).

The result of the sequence of nucleotide bases supported by bioinformatics services derived isolates 1 (of endophyte best rod 1) was Lasiodiplodia euphorbicola, isolates 2 (origin endophyte best rind 2) was Diaporthe tectonae, isolate 3 (origin of the best leaf endophytic 3), namely Colletotrichum siamense, isolate 4 (origin endophyte best rod 4) was Candida parapsilogis, and isolates 5 (origin of best leaf endophytic) was Aspergillus sydowii and isolates 6 (origin endophyte best rind 6) was Aspergillus flavus.

\section{Inhibition ability test}

Inhibition ability test for six endophytic fungi on the growth of $P$. palmivora in vitro studies suggest that endophytic stem 3 (L. euphorbicola) with $91.11 \%$ inhibition, followed by endophytic rind 4 (D. tectonae) and endophytic leaf 2 (C. siamense) respectively by $66.66 \%$, then endophytic rind $3(A$. flavus) amounted to $65.92 \%$, endophytic stem 2 ( $C$. parapsilogis) amounted to $62.96 \%$ and $55.55 \%$ for leaf endophytic 5 (A. sydowii) (Figs. 2 and 3). 


\section{Antagonistic test in vivo}

Test antagonist in vivo indicated that the treatment with the antagonist fungus, L. euphorbicola gave the best results among the other treatments with
D. tectonae, C. siamense, A. flavus, C. parapsilogis, A. sydowii), with a disease incidence of $0 \%$, followed by $D$. tectonae by $25 \%, C$. siamense by $35 \%$, then A. flavus, A. sydowii, and C. parapsilogis $100 \%$ respectively (Table 1, Fig. 4).

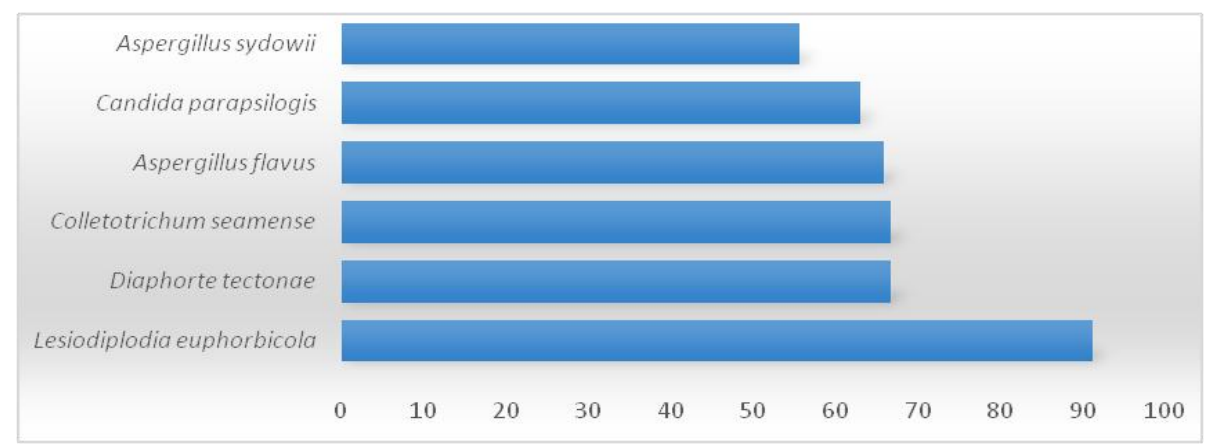

Fig. 2: Inhibition ability of endophytic fungus on P. palmivora in vitro.
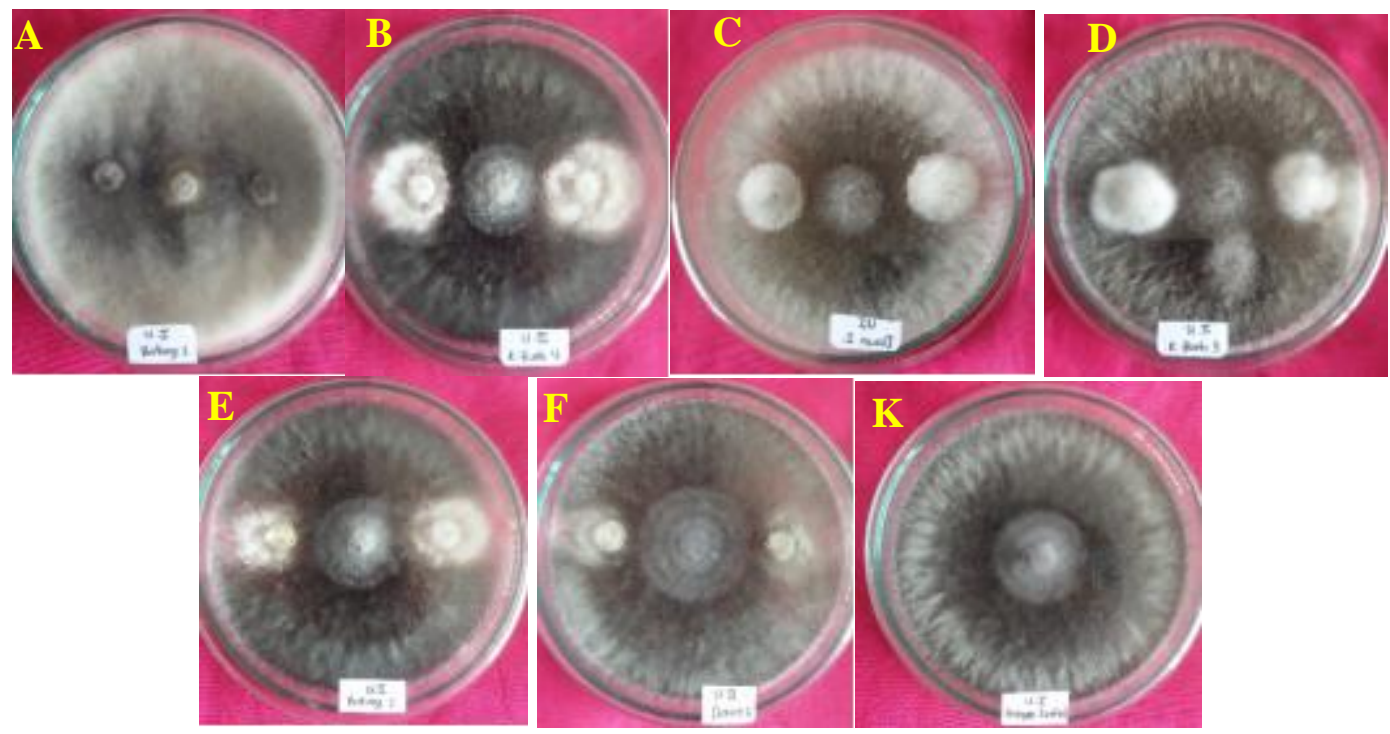

Fig. 3: Inhibition ability test of endophytic fungus on $P$. palmivora in vitro, $\mathrm{A}=$ Lasiodiplodia euphorbicola, $\mathrm{B}=$ Diaporthe tectonae, $\mathrm{C}=$ Colletotrichum siamense, $\mathrm{D}=$ Aspergillus flavus, $\mathrm{E}=$ Candida parapsilogis, $\mathrm{F}=$ Aspergillus sydowii, and $\mathrm{K}=\mathrm{control}$ (P. palmivora) (7 days after inoculation)

Table 1. Percentage of fruit infected by P. palmivora each endophytic fungus treatment.

\begin{tabular}{lll}
\hline Treatment & Percentage of fruit infected & Notation* \\
\hline $\mathrm{A}=$ control (without antagonistic without pathogen) & 100 & $\mathrm{D}$ \\
$\mathrm{B}=$ Lasiodiplodia euphorbicola & 0 & $\mathrm{~A}$ \\
$\mathrm{C}=$ Diaporthe tectonae & 25 & $\mathrm{~B}$ \\
$\mathrm{D}=$ Colletotrichum siamense & 35 & $\mathrm{C}$ \\
$\mathrm{E}=$ Aspergillus flavus & 100 & $\mathrm{D}$ \\
$\mathrm{F}=$ Candida parapsilogis & 100 & $\mathrm{D}$ \\
$\mathrm{G}=$ Aspergillus sydowii & 100 & $\mathrm{D}$ \\
$\mathrm{H}=$ control (without antagonistic with pathogen) & 100 & $\mathrm{D}$ \\
\hline
\end{tabular}

*The same letter in the same column showed no significant difference in the LSD 5\%. Data were analyzed after transformed into the form $\mathrm{Vx}+0.5$. 


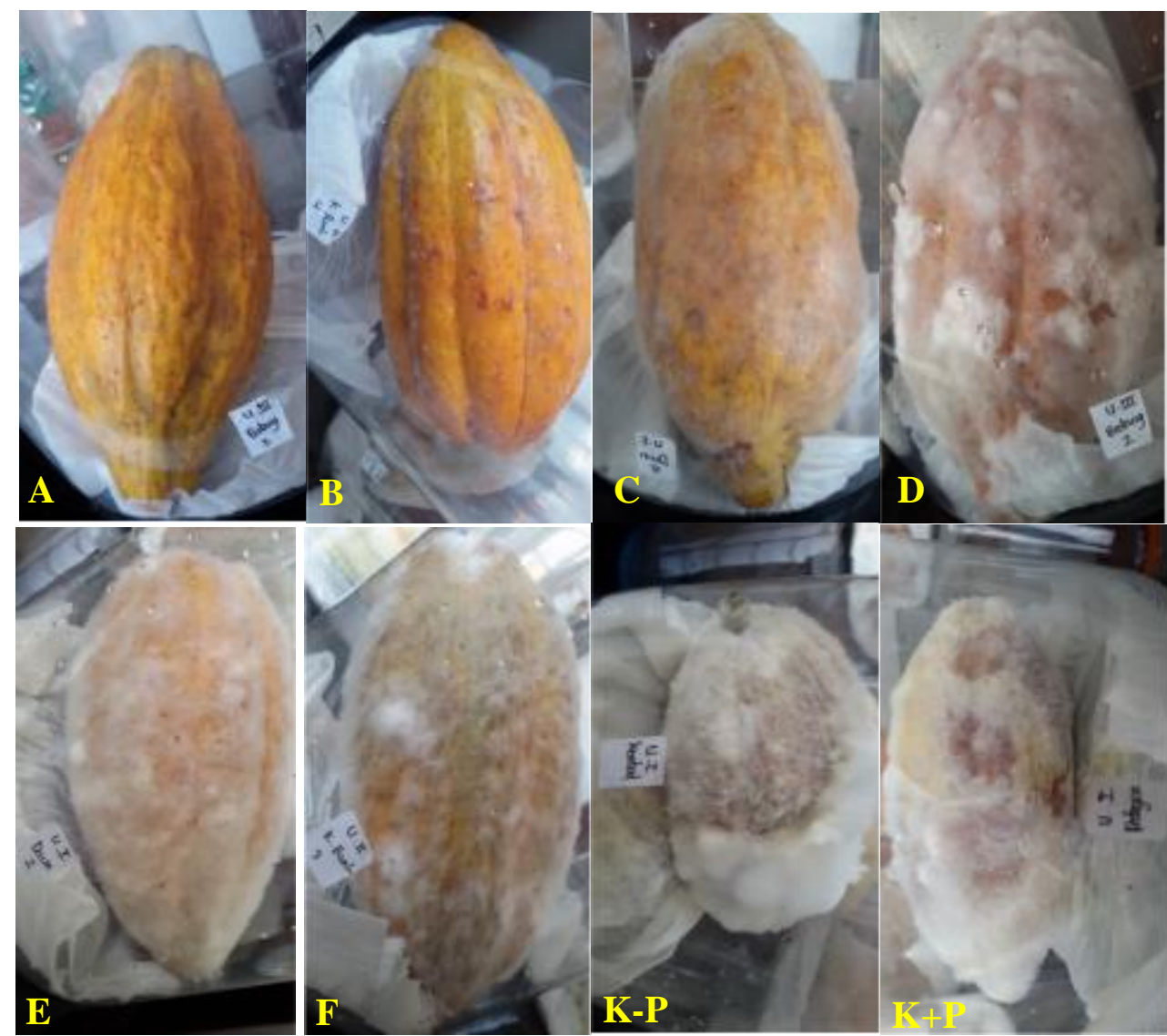

Fig. 4: Antagonistic test in vivo, $\mathrm{A}=$ Lasiodiplodia euphorbicola, $\mathrm{B}=$ Diaporthe tectonae, $\mathrm{C}=$ Colletotrichum siamense, $\mathrm{D}=$ Aspergillus flavus, $\mathrm{E}=$ Candida parapsilogis, $\mathrm{F}=$ Aspergillus sydowii, $\mathrm{K}-\mathrm{P}=$ control without $P$. palmivora, and $\mathrm{K}+\mathrm{P}=$ control with $P$. plamivora $(7$ days after inoculation)

\section{Antagonistic test in the field}

The success of the inhibition ability test in vivo, followed by success in the field test by using a single type of antagonist, namely L. euphorbicola. Seem increasingly concentrated suspension of spore are getting better at pressing $P$. palmivora on cacao black pod. With a spore suspension concentration of the Petri dish $150 \mathrm{ml}$ of sugar solution plus the percentage of infected fruit reached $15 \%$, followed by the concentration of sugar solution of $200 \mathrm{ml}$ and $250 \mathrm{ml}$ together with the percentage of infected fruit $20 \%$, then followed by the addition of sugar solution of $500 \mathrm{ml}$ and $1000 \mathrm{ml}$ with the percentage of infected fruit respectively by $25 \%$ and $30 \%$ (Table 2, Fig. 5).

Table 2. Disease incidence of P. palmivora on fruit in the field.

\begin{tabular}{|c|c|c|c|c|c|c|c|}
\hline \multirow{2}{*}{ Treatment } & \multicolumn{5}{|c|}{ Number of black pod rot (repeats) } & \multirow{2}{*}{$\begin{array}{l}\text { Average } \\
(\%)\end{array}$} & \multirow{2}{*}{$\begin{array}{l}\text { Fruit that can } \\
\text { be saved }\end{array}$} \\
\hline & 1 & 2 & 3 & 4 & 5 & & \\
\hline Control & 75 & 75 & 100 & 100 & 100 & $90 \mathrm{a}^{*}$ & \\
\hline L. euphorbicola $(150 \mathrm{ml})$ & 50 & 0 & 0 & 25 & 0 & $15 \mathrm{~b}$ & 75 \\
\hline L. euphorbicola $(200 \mathrm{ml})$ & 0 & 25 & 50 & 25 & 0 & $20 \mathrm{~b}$ & 70 \\
\hline L. euphorbicola $(250 \mathrm{ml})$ & 0 & 50 & 25 & 25 & 0 & $20 \mathrm{~b}$ & 70 \\
\hline L. euphorbicola $(500 \mathrm{ml})$ & 75 & 0 & 25 & 0 & 25 & $25 \mathrm{~b}$ & 65 \\
\hline L. euphorbicola $(1000 \mathrm{ml})$ & 50 & 0 & 25 & 25 & 50 & $30 \mathrm{~b}$ & 60 \\
\hline
\end{tabular}

*The same letter in the same column showed no significant difference in the level of LSD 5\%. 


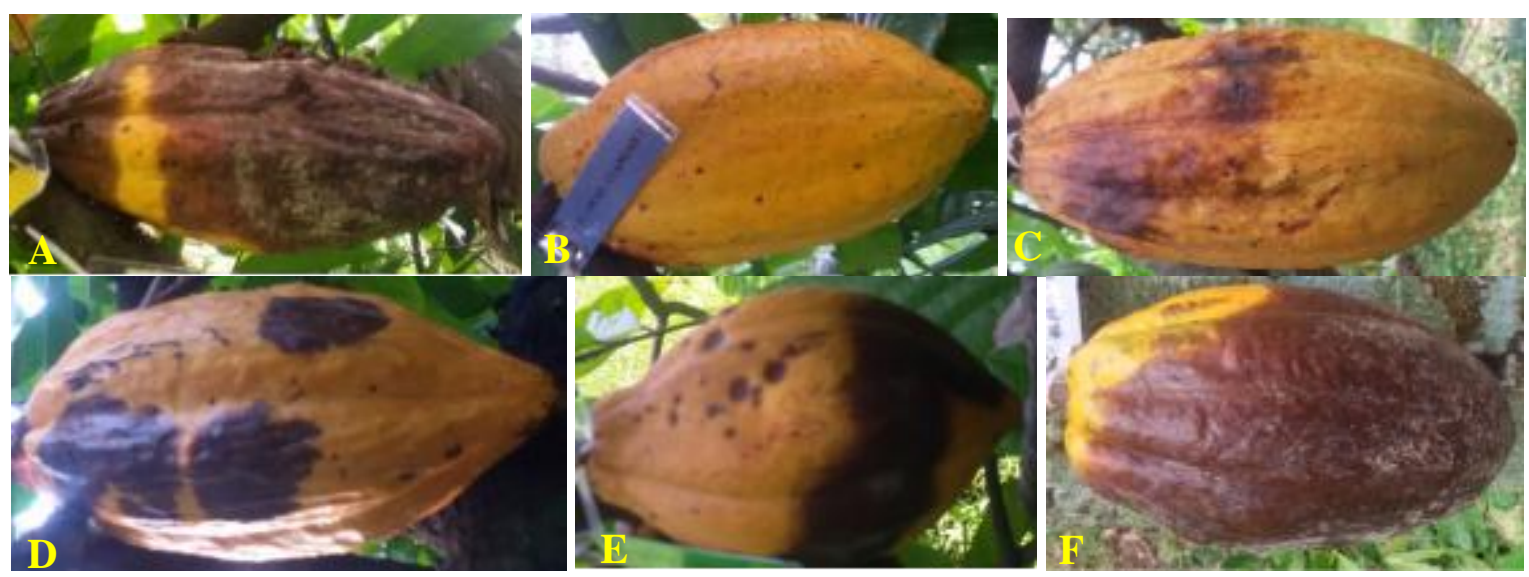

Fig. 5: Endophytic fungus treatment effect against $P$. palmivora, $\mathrm{A}=\mathrm{Control}$ (without treatment), $\mathrm{B}=$ L. euphorbicola $(150 \mathrm{ml}), \mathrm{C}=$ L. euphorbicola $(200 \mathrm{ml}), \mathrm{D}=$ L. euphorbicola $(250 \mathrm{ml})$, $\mathrm{E}=$ L. euphorbicola $(500 \mathrm{ml})$ and $\mathrm{F}=$ L. euphorbicola $(1000 \mathrm{ml})$ age of 21 days after inoculation.

\section{Discussion}

Lasiodiplodia euphorbicola was isolated, which is one cause of the die back disease on the grapevine plants. These pathogens secrete metabolite (-) mellein, (3R, 4R) - (-) - and (3R, 4S) - (-) - 4hydroxymellein and tyrosol. Activities phytotoxic metabolites produced also discussed related symptoms these pathogens that cause disease in grapevines (Cimmino et al., 2017). Results showed that $L$. euphorbicola showed inhibition against $P$. palmivora best. The fungus Diaporthe tectonae was isolated from soil in Jeon-ju Korea. The isolation is characterized by morphological and phylogenetic analysis using a set of data that is combined with the internal transcribed spacer, $\beta$-tubulin, and long sequences of 1- $\alpha$ factor that indicates similar to the strain D. tectonae (Park et al., 2017). Candida parapsilogis is a fungus that cause disease in humans is able to colonize on the skin, proliferation in a solution containing the sugar and attached to a plastic (Asbeck et al., 2009). Aspergillus sydowii been isolated from marine sponges (Spongia obsura) cause of illness in the growth of rock in the Caribbean sea (Ein-Gil et al., 2009), while A. flavus is a major producer of known aflatoxin human carcinogen (Rodrigues et al., 2007).

Endophytic fungi (L. euphorbicola) can suppress the development of fungus $P$. palmivora in the field. The larger the solvent in the form of sugar solution (10\%) given the smaller pieces that can be saved, as evidenced by a solution of $150 \mathrm{ml}$ of fruit sugars that can be saved by $75 \%$, and vice versa. The magnitude of the attack of pathogens in the field depends on the source of inoculum. The bigger and near the source of inoculum from healthy fruit, the greater the chance of infection. The reality on the ground that the source of inoculum evenly and planted cultivars are susceptible to $P$. palmivora.

\section{Conclusion}

Based on the results of the present study, it can be summarized as follows: fungal antagonists identified based on the sequences of DNA were Lasiodiplodia euphorbicola, Diaporthe tectonae, Colletotrichum siamense, Aspergillus flavus, Candida parapsilogis, and Aspergillus sydowii. Meanwhile, results of inhibition are best shown by the endophytic fungi L. euphorbicola. Field trials showed the higher the concentration the better the power spore suspension suppress fungal antagonists against $P$. palmivora. The best concentration that colonies of the Petri dish was dissolved in $150 \mathrm{ml}$ of sugar solution $(10 \%)$..

\section{Conflict of interest statement}

Authors declare that they have no conflict of interest. 


\section{Acknowledgement}

Authors wish to thank to Rector of Udayana University for their assistance and the opportunity given so that research can be resolved, Dean of the Faculty of Agriculture, Udayana University, and Chairman of the Institute for Research and Community Service Udayana University, for the financial support.

\section{References}

Amadi, J.E., 2005. Endophytic and exopjhytic fungi isolated from the seeds of Tetracapidium cocophorum in Ilorin, Nigeria. Nig. J. Pure Appl. Sci. 20, 1757-1761.

Arnold, A.E., Mejia, L.C., Kyllo, D., Rojas, E., Maynard, Z., Robbins, N., Herre, E.A., 2003. Fungal endophytes limit pathogen damage in a tropical tree. Proc. Nat. Acad. Sci. (USA). 100, 15649-15654.

Arnold, A.E., Maynard, Z., Gilbert, G. S., 2000. Are tropical fungal endophytic hyperdiverse? Ecol. Lett. 3, 267-274.

Asbeck, E.C., Clemons, K. V., Stevens, D.A., 2009. Candida parapsilosis: A review of its epidemiology, pathogenesis, clinical aspects, typing and antimicrobial suspectibility. Crit. Rev. Microbiol. 35(4), 283-309.

Bateman, R., 2002. Best-bet solution for cacao diseases. Gro-Cacoa Newslett. 1, 4-5.

CAB International, 2014. Black Pod Disease. Crop Protection Copendium 19/03/2014.

Cimmino, A., Cinelli, T., Masi, M., Reveglia, P., Araujo da Silva, M., Mugnai, L., Machereff, S. J., Surico, G., Evidente, A., 2017. Phytotoxic lipophilic metabolites produced by grapevine starins of Lasiodiplodia species in Brazil. J. Agric. Food Chem. 65(6), 1102-1107.

Clay, K., Schardl, C., 2002. Evolutionary origins and ecological consequences of endophytie symbiosis with grasses. Amer. Natural. 160, 99-127.

Correia, K.C., Silva, M.A., de Morais, M.A., Amengol, J., Phillips, A. J. L., Camara, M. P. S., Michereff, S. J., 2016. Phylogeny, distribution and pathogenicity of Lasiodiplodia species associated with dieback of table grape in the main Brazilian exporting region. Plant Pathol. 65(1), 92-103.

Directorate General of Estate Crops, 2014. Tree Crop Estate Statistics of Indonesia 2013-2015 Cocoa. Jakarta.

Dwarka, D.J., Sharma, G., Rasajab, A.H., 2016. Colletotrichum siamense causes anthracnose on the fruits of Pongamia pinnata in India. Mycosphere. 7(4), 492-498.

Ein-Gil, N., Ilan, M., Garneli, S., Smith, G. W., Pawlik, J. R., Yarden, O., 2009. Presence of Aspergillus sydowii, a pathogen of gorgonian sea fans in the marine sponge Spongia obcura. ISME J. 3, 752-755.

Evans, H.C., Holmes, K.A., Thomas, S.E., 2003. Endophytes and mycoparasites associated with an ingenous forest tree. Theobroma gileri, in Ecuador and preliminary assessment of their potential as biocontrol agents of cacoa diseases. Mycol. Progr. 2, 149-160.

Faeth, S.H., 2002. Are endophytic fungi defensive plant mutulists? Oikos. 98, 25-36.

Gwinn, K.D., Gavin, A.M., 1992. Relationship between endophyte infestation level of tall fascue seed lots and Rhizoctiniazeae seedling disease. Plant Dis. 76, 911-914.

Hallman, J., Sikora, R., 1995. Influence of Fusarium oxysporum, a mutualistic fungal endophyte, on Meloidogyne incognita infection of tomato. J. Plant Dis. Prot. 101, 475-481.

Herre, E.A., Knowlton, N., Muller, U., Rehner, S., 1999. The evolution of mutualisms: Exploring the paths between conflict and cooperation. Trend. Ecol. Evol. 14, 49-53.

Jackson, G. H.V. H., Wright, J.G., 2001. Black pod and cancer of cocoa. Plant Protectuon Service. Secretariat of the Pasific Community. Pest Advisory Leaflet No. 7.

Langvad, F., 1980. A simple and rapid method for qualitative and quantitative study of the fungal flora ofleaves. Can. J. Bot. 26, 666-670.

Leben, C., 1965. Epiphytic micro-organisms in relation to plant diseases. Annu. Rev. Phytopathol. 2, 209-230.

Malinowski, D., Braurer, D. K., Belesky, D.P., 1999. The endophyte Neotyphodium coenophialum affects root morphology of all 
fecue grown under phosphorous deficiency. J. Agron. Crop. Sci. 183, 53-60.

Mejfa, L.C., Rojas, E. I., Maynard, Z., Bael, S. V., Arnold, A. E., Hebbar, P., Damuels, G. J., Robbins, N., Herre, E. A., 2008. Endophytic fungi as biocontrol agents of Theobroma cacao pathogens. Biol. Cont. 46, 4-14.

Mojica-Marin, V., Luna-Olvera, H. A., Fco, C., Sandoval-Coronado, Pereyra-Alférez, B., Lilia, H., Morales-Ramos, Carlos, E., HernándezLuna, Alvarado-Gomez, G. O., 2008. Antagonistic activity of selected strains of Bacillus thuringiensis against Rhizoctonia solani of chili pepper. Afr. J. Biotechnol. 7(9), 1271-1276.

Nandhini, S., Sendhilvel, V., Babu, S., 2012. Endophytic bacteria from tomato and efficacy against Fusarium oxusporum f.sp. lycopersici, the wilt pathogen. J. Biopest. 5(2), 178-185.

Norse, D., 1972. Fungal populations of tobacco leaves and their effect on the growth of Alternaria longipes. Trans. British Mycol. Soc. 59, 261-271.

Park, S., Seung-Yeo, L., Jae-Jin, L., Chang-Gi, B., Lee, H. B., Hee-Young, J., 2017. First report of Diaporthe tectonae isolated from soil in Korea. Korea J. Mycol. 45, 83-89.

Phillips-Mora, W., Cerda, R., 2009. Catalog Cacao Diseases in Central America. Technical Series. Technical Manual No.93. Tropical Agricultural Research and Higher Education Center (CATIE) Turrialba, Costa Rica.

Pocasangre, L., Sikora, R. A., Vilich, V., Schuster,
R. P., 2001. Survey of banana endophytic fungi from Central America and screening for biological control of burrowing nematode (Rhalopholus semilis). Acta Hortic. 119, 795804.

Rodrigues, P., Soares, C., Kozakiewicz, Z., Paterson, R. R. M., Lima, N., Venancio, A., 2007. Identification and characterization of Aspergillus flavus and aflatoxins. In Communicating Current Research and Educational Topics and Trends in Applied Microbiology (Ed.: Mendez-Vilas, A.). Formatex. pp.527-534.

Saha, A.K., Ray, A., Das, P., 2013. Fungal colonization of philloplane of Psidium guineese Sw. growing in Suryamanigar, Tripura Northeast India. Int. J. Basic Appl. Chem. Sci. 3(1), 62-67.

USDA CSREES, 2018. Ny. Phytophthora palmivora. Pest and Diseases of American Samoa Number 12. American Samoa Community College. Community and Natural Resources. Cooperative Research and Extension. http://forestphytophthoras.org/sites/ default/files/educational_materials/P.\%20palmi vora\%20-\%20BrochureNo12.pdf

Wilson, D., 1995. Endophytic-The evolution of a term and clarification of its use and definition. Oikos. 73, 274-276.

Yadav, S. L., Mishra, A. K., Dongre, P. N., Singh, R., 2011. Assessment of fungixicity of phylloplane fungi against Alternaria brassicae causing leaf spot of mustard. J. Agric. Technol. 7(6), 1923-1831.

\section{How to cite this article:}

Made Sudarma, I., Suniti, N. W., Darmiati, N, N., 2018. Endophytic fungi with potential as biological control agents for black pod rot disease [Phytophthora palmivora (Butler) Butler]. Int. J. Curr. Res. Biosci. Plant Biol. 5(5), 41-48. doi: https://doi.org/10.20546/ijcrbp.2018.505.007 